\title{
RELEVANSI DISKUSI KELOMPOK UNTUK MENINGKATKAN KEMAMPUAN GURU AGAMA HINDU DALAM MENYAJIKAN PEMBELAJARAN INOVATIF
}

\author{
Oleh: \\ I Made Arka \\ Kantor Kementerian Agama Kabupaten Gianyar \\ drs.imadearka@gmail.com
}

\begin{abstract}
Technological advances provide many offers and options for the education to support the learning process so that the learning processes become more effective and efficient for the learners. The group discussion among classroom teachers in the form of KKG to discuss the problem of utilizing the school environment as a source oflearning to be relevant is applied. The focus of this study is the improvement of the ability of the teachers in presenting innovative learning through the use of school environment as a source of learning through the discussion of teacher work group in the Elementary School Cluster I Blahbatuh District Gianyar Regency year lesson 2014/2015. Based on the results of the research, there is relevance to the improvement of the teachers' ability in presenting innovative learning with the utilization of school environment as a learning resource through teacher work group discussion approach in Blahbatuh District at the Elementary School Cluster, Gianyar Regency lesson year $2014 / 2015$.
\end{abstract}

Keywords: Group discussion, Innovative learning

\begin{abstract}
Abstrak
Kemajuan teknologi memberikan banyak tawaran dan pilihan bagi dunia pendidikan untuk menunjang proses pembelajaran sehingga pembelajaran menjadi lebih efektif dan efisien bagi peserta didik. Diskusi kelompok antar guru kelas dalam bentuk KKG untuk mendiskusikan masalah pemanfaatan lingkungan sekolah sebagai sumber belajar menjadi relevan diterapkan. Fokus studi ini adalah peningkatan kemampuan guru dalam menyajikan pembelajaran Inovatif melalui pemanfaatan lingkungan sekolah sebagai sumber belajar melalui diskusi Kelompok Kerja Guru (KKG) dipada Sekolah Dasar Gugus I Kecamatan Blahbatuh Kabupaten Gianyar Tahun Pelajaran 2014/2015. Berdasarkan hasil penelitian, ada relevansi peningkatan kemampuan guru dalam menyajikan pembelajaran Inovatif dengan pemanfaatan lingkungan sekolah sebagai sumber belajar melalui pendekatan diskusi kelompok kerja guru (KKG) di Sekolah Dasar Gugus Kecamatan Blahbatuh, Kabupaten Gianyar Tahun Pelajaran 2014/2015.
\end{abstract}

Kata Kunci: Diskusi kelompok, Pembelajaran inovatif 


\section{PENDAHULUAN}

Pendidikan agama Hindu seperti dijelaskan dalam buku Himpunan Keputusan Seminar Kesatuan Tafsir terhadap Aspek-aspek Agama Hindu-XV, dibedakan atas dua bagian yaitu pendidikan agama Hindu di luar sekolah, dan pendidikan agama Hindu di lingkungan sekolah. Pengertian kedua jenis pendidikan agama Hindu dimaksud dijelaskan sebagai berikut : 1) pengertian pendidikan agama Hindu di luar sekolah yaitu : Suatu upaya untuk membina pertumbuhan jiwa masyarakat dengan ajaran agama Hindu itu sendiri sebagai pokok materi; dan 2) pengertian pendidikan agama Hindu di sekolah yaitu suatu upaya untuk membina pertumbuhan jiwa raga anak didik susuai dengan ajaran agama Hindu (Tim Penyusun, 1985:23).

Sehubungan dengan hal itu pendidikan agama Hindu diupayakan agar terlaksana dengan baik berkesinambungan sehingga tercipta keharmonisan hidup di dalam individu umat itu sendiri, intern umat beragama, serta antar umat beragama dalam mewujudkan kedamaian hidup. Terkait dengan pelaksanaan pembelajaran agama Hindu di sekolah dasar, rupanya materi agama kurang begitu diminati pada jenjang pendidikan dasar, hal ini tidak terlepas dari materinya yang cendrung sulit untuk dipahami, terlebih lagi ketika cara guru dalam menyajikanya kurang menyenangkan. Dari hasil observasi awal yang dilakukan peneliti yang juga merupakan pengawas agama Hindu ada beberapa hal yang mempengaruhi rendahnya motivasi belajar agama Hindu, antara lain: Pendekatan pembelajaran lebih banyak didominasi oleh peran guru, dan guru satusatunya sumber belajar,selain buku paket. Pembelajaran yang dikembangkan di kelas kelas kelihatannya lebih ditekankan pada pemikiran reproduktif, menekankan pada hafalan dan mencari satu jawaban benar terhadap soal-soal yang diberikan. Dalam kegiatan pembelajaran guru belum mampu menerapkan model, motode atau setrategi pembelajaran yang sesuai dengan karakteristik materi yang diajarkan sehingga kurang mengembangkan daya nalar siswa secara optimal, dan kurang menyenangkan.

Salah satu setrategi pembelajaran yang sesuai dengan pendekatan Paikem yang memungkinkan bisa mengembangkan kreativiats, motivasi dan partisipasi siswa dalam pembelajaran adalah dengan memanfaatkan lingkungan sekolah sebagai sumber belajar. Hal ini juga sesuai dengan salah satu pilar dari pendekatan contekstual yaitu masyarakat belajar (learning commonity). Untuk mencapai tujuan tersebut, salah satu cara belajar yang disarankan dalam KTSP sebagai upaya mendekatkan aktivitas belajar siswa pada berbagai fakta kehidupan sehari-hari di sekitar lingkungan siswa. Memanfaatkan lingkungan sekolah sebagai sumber belajar menjadi alternatif setrategi pembelajaran untuk memberikan kedekatan teoritis dan praktis bagi pengembangan hasil belajar siswa secara optimal. Pembelajaran yang bersentuhan langsung dengan realita akan berimplikasi pada terbentuknya pemahaman siswa secara mendalam dan seksama terkait dengan pokok bahasan dan materi pembelajaran. Misalnya saja ketika membahas tentang tempat suci agama Hindu siswa dapat dihadapkan langsung dengan padmasana sekolah sebagai salah satu sumber belajar, serta sumber belajar lainya di lingkungan sekolah bersangkutan.

Dari hasil pantauan calon peneliti selaku pengawas sekolah, selama ini para guru masih sangat jarang memanfaatkan lingkungan sekolah sebagai sumber belajar. Lingkungan sekolah tidak lebih hanya digunakan sebagai tempat bermain-main siswa pada saat istirahat. Kalau tidak jam istirahat, guru lebih sering memilih mengkarantina siswa di dalam kelas, walaupun misalnya siswa sudah merasa sangat jenuh berada di dalam kelas. Observasi awal yang dilakukan di Sekolah Dasar Gugus I Kecamatan Blahbatuh Kabupaten Gianyar, yang merupakan wilayah binaan dari peneliti, guruguru di sekolah tersebut memanfaatkan lingkungan sekolah sebagai sumber belajar hanya dua sampai tiga kali dalam satu semester. Guru lebih sering menyajikan pelajaran di dalam kelas walaupun materi yang disajikan berkaitan dengan lingkungan sekolah. Dari wawancara yang dilakukan calon peneliti, sebagian besar guru mengaku enggan mengajak siswa belajar di luar kelas, karena alasan susah mengawasi. Selain itu ada guru yang menyampaikan bahwa mereka tidak bisa dan tidak tahu dalam memanfaatkan lingkungan sekolah sebagai sumber belajar. 
Untuk mengatasi hal itu perlu adanya diskusi kelompok diantara para guru kelas dalam bentuk KKG untuk mendiskusikan masalah pemanfaatan lingkungan sekolah sebagai sumber belajar. Dalam kegiatan diskusi tersebut para guru bisa membagi pengalaman dalam pemanfaatan lingkungan sekolah sebagai sumber belajar untuk mencapai hasilbelajar yang optimal. Penelitian Nur Mohamad dalam Ekowati (2001) menunjukkan diskusi kolompok memiliki dampak yang amat positif bagi guru yang tingkat pengalamannya rendah maupun yang tingkat pengalamannya tinggi. Sehingga beranjak dari hal tersebut dalam penelitian ini penulis mencoba mengkaji tentang Relevansi Kegiatan KKG Agama Hindu Dalam Meningkatkan Kemampuan Guru Menyajikan Pembelajaran Inovatif melalui Pemanfaatan Lingkungan Sekolah pada guru Agama Hindu Gugus I Kecamatan Blahbatuh Kabupaten Gianyar.

\section{MATERI DAN METODE}

Kelompok Kerja Guru (KKG) adalah bentuk kegiatan yang beranggotakan guru-guru kelas, dimana tujuan kegiatannya adalah untuk meningkatkan kemampuan dan kompetensi mereka sesuai kelas yang dipegang. Bentuk kegiatan KKG bisa berupa diklat, simulasi, diskusi atau yang lainnya. Kemudian diskusi kelompok adalah suatu kegiatan belajar yang dilakukan secara bersama-sama. Diskusi kelompok pada dasarnya memecahkan persoalan secara bersama-sama. Artinya setiap anggota turut memberikan sumbangan pemikiran dan pendapat dalam memecahkan persoalan tersebut. Diskusi kelompok adalah suatu kegiatan belajar untuk memecahkan persoalan secara bersama-sama, sehingga akan memperoleh hasil yang lebih baik. (Tabrani dan Daryani dalam Kasianto, 2004).

Berdasarkan uraian di atas, dapat disimpulkan bahwa diskusi kelompok adalah suatu proses usaha yang dilakukan individu untuk memperoleh perubahan tingkah laku sebagai pengalaman individu dalam interaksinya dengan lingkungan yang dilakukan secara bersama-sama atau berkelompok. Ischak S.W. dan Warji R. (dalam Kasianto,2004) mengemukakan beberapa petunjuk dalam pelaksanaan diskusi kelompok, yaitu: (a) Pilihlah teman yang cocok untuk bergabung dalam belajar kelompok. Jumlah setiap kelompok terdiri dari 5 hingga 7 orang; (b) Tetapkan siapa sebagai pemimpin yang akan memimpin jalannya diskusi atau belajar kelompok; (c) Hentaskan persoalan satu persatu dengan memberi kesempatan kepada anggota untuk mengajukan pendapatnya. Dari pendapat yang masuk dikaji bersama-sama mana yang paling tepat.

Subjek penelitian ini adalah 10 orang guru mata pelajaran agama Hindu Sekolah Dasar gugus Blahbatuh di Kecamatan Blahbatuh Kabupaten Gianyar yang meliputi guru agama Hindu SDN 1 Blahbatuh s/d SDN 5 Blahbatuh. Objek penelitian ini adalah kemauan dan kemampuan guru-guru agama Hindu tingkat sekolah Dasar Gugus I Kecamatan Blahbatuh dalam menyajikan pembelajaran Inovatif melalui pemanfaatan Lingkungan Sekolah sebagai Sumber Belajar. Kegiatan observasi dilaksanakan bersamaan dengan pelaksanaan tindakan yaitu pada saat diskusi KKG baik pada pertemuan I, II dan III. Tahap observasi bertujuan untuk mengetahui kerjasama ,kreativitas,perhatian,maupun presentasi yang dilakukan guru dalam menyusun skenario pembelajaran maupun dalam melaksanakan pembelajaran dengan memanfaatkan lingkungan sekolah sebagai sumber belajar. Adapun skala penilaian yang digunakan adalah skala Likert dengan 5 katagori sikap yaitu: sangat tinggi, tinggi, rendah, sedang dan sangat rendah.

\section{PEMBAHASAN DAN DISKUSI}

\subsection{Siklus I}

Berdasarkan pengamatan awal pada Sekolah Dasar Gugus Blahbatuh, Kecamatan Blahbatuh , Kabupaten Gianyar, semua guru kelas dan guru bidang studi jarang dan bahkan tidak pernah memanfaatkan lingkungan sekolah sebagai sumber belajar,hal ini disebabkan oleh kurangnya pemahaman dan kemampuan guru untuk memanfaatkan lingkungan sekolah sebagai sumber belajar. Selama ini guru lebih banyak menggunakan buku paket dan alat peraga yang dimiliki sekolah sebagai sumber belajar untuk melengkapi kegiatan pembelajaran di kelas. Demikian pula kegiatan pembelajaran di luar kelas sangat jarang dan bahkan tidak pernah dilakukan dengan alasan tidak cukup 
waktu, masalah keamanan dan keselamatan siswa. Hal ini sudah tentu kurang sesuai dengan pembelajaran yang menggunakan pendekatan pembelajaran aktif, kreatif, efektif dan menyenangkan(Pakem) yang harus dilaksanakan dalam penterapan kurikulum tingkat satuan pendidikan (KTSP). Kegiatan dalam siklus I ini, diawali dengan kegiatan diskusi kelompok kerja guru (KKG) tentang permasalahan yang dihadapi dalam pemanfaatan lingkungan sekolah sebagai sumber belajar, dilanjutkan dengan informasi tentang manfaat lingkungan sekolah sebagai sumber belajar bagi siswadan implementasinya dalam proses belajar mengajar.

Data penelitian tindakan sekolah yang diperoleh dari hasil observasi sikap guru dalam kegiatan diskusi kelompok kerja guru tentang pemanfaatan lingkungan sekolah sebagai sumber belajar pada siklus I,hasilnya termasuk katagori"cukup" dengan rata-rata nilai 79,00. Hal ini menunjukkan bahwa guru dalam berdiskusi belum menampakkan kerjasama, aktivitas dan perhatian yang baik terhadap permasalahan pemanfaatan lingkungan sekolah sebagai sumber belajar ,sehingga diperlukan bimbingan yang lebih intensif.

Penilaian implementasi pemanfaatan lingkungan sekolah sebagai sumber belajar dalam kegiatan pembelajaran di kelas, hasilnya termasuk katagori "cukup" dengan rata-rata nilai 79.2. Presentase guru yang memenuhi kriteria pada siklus I mencapai $60 \%$ yakni dari 10 orang guru yang menjadi subjek penelitian ada 4 orang guru yang belum memenuhi criteria yang ditetapkan. Hal ini menunjukkan bahwa guru dalam mengimplementasikan pemanfaatan lingkungan sekolah sebagai sumber belajar melalui kegiatan pembelajaran di kelas belum optimal,sehingga perlu peningkatan.Dengan adanya hasil observasi dan penilaian pada kegiatan siklusI maka peneliti melakukan refleksi. Dari refleksi terhadap seluruh kegiatan pada siklus I, maka ditemukan beberapa hambatan yang mengakibatkan belum optimalnya kemampuan guru memanfaatkan lingkungan sekolah sebagai sumber belajar.

Adapun hambatan-hambatan tersebutantara lain guru belum sepenuhnya memahami manfaat lingkungan sekolah sebagai sumber belajar, dan guru dalam memilih sumber belajar dan memilih strategi pembelajaran dengan memanfaatkan lingkungan sekolah belum sesuai dengan yang diharapkan. Hal ini terlihat dalam skenario pembelajaran guru pada: aspek 1.jenis sumber belajar dari lingkungan sekolah tidak tercantum, padahal materi pelajaran ada kaitannya dengan lingkungan sekolah;. aspek 2. Kesesuaian antara materi pelajaran dengan media dan setrategi pembelajaran masih kurang; aspek 4.Kesesuaian antara tujuan pembelajaran dengan sumber bahan,lebih banyak hanya mencantumkan buku paket sebagai satu-satunya sumber belajar.

Dari hasil refleksi pelaksanaan pembelajaran di kelas, hambatan-hambatan yang ditemukan adalah sebagai berikut : aspek 1.dalam kegiatan awal,guru tidak memberi informasi tujuan pembelajaran dan waktunya belum sesuai dengan perencanaan; aspek 2.kegiatan inti, langkah-langkah pembelajaran masih didominasi guru dengan metode ceramah sehingga kurang sesuai dengan pembelajaran aktif, kreatif, efektif dan menyenangkan (Pakem); aspek3. Kemampuan guru mengkaitkan materi pelajaran dengan lingkungan sekolah belum optimal; aspek 6 . Penutup pelajaran, gurukurang memberi penekanan tentang lingkungan sekolah. Hambatan-hambatan tersebut akan disempurnakan pada kegiatan siklus II.

\subsection{Siklus II}

Pada siklus II, kegiatan yang dilaksanakan adalah mendiskusikan hambatan- hambatan yang dialami dalam menyusun skenario pembelajaran dan pelaksanaan pembelajaran di kelas pada siklus I melalui kegiatan kelompok kerja guru (KKG). Adapun secara rinci uraian kegiatannya sebagai berikut :

Dalam penyusunan skenario pembelajaran khususnya pada aspek 1,2 dan 4 guru melakukan revisi, dipandu oleh guru yang sudah mampu,dengan bimbingan peneliti/pengawas. Dalam pelaksanaan pembelajaran di kelas,terkait dengan hambatan pada aspek 1.kegiatan awal, aspek 2.kegiatan inti, aspek 3.kemampuan guru mengkaitkan materi pelajaran dengan lingkungan sekolah ,dan aspek 6.penutup pelajaran, maka guru mendiskusikan kembali hambatan tersebut dalam kelompok kerja guru (KKG) dibimbing pengawas/peneliti. Sebelum pelaksanaan pembelajaran di kelas, terlebih dahulu dilakukan simulasi atau modeling 
dengan menggunakan anggota kelompok guru sebagai siswa.Sebagaimana kegiatan peneliti pada siklus I, maka kegiatan pada siklus keduapun dilakukan observasi, evaluasi dan penilaian.

\subsection{Pembahasan Hasil Penelitian}

Secara umum tahapan-tahapan pelaksanaan pembelajaran Inovatif melalui pemanfaatan Lingkungan sekolah sebagai sumber belajar yang dilakukan sudah sesuai dengan rencana. Hasil observasi yang dilakukan terhadap pelaksanaan tindakan yang dilakukan tampak bahwa beberapa indikator yang digunakan sebagai acuan mengobservasi pelaksanaan, tampak bahwa semuanya (sudah dijalankan dengan baik)

Adapun data atau hasil yang diperoleh selama pelaksanaan pembelajaran Inovatif melalui pemanfaatan Lingkungan sekolah sebagai sumber belajar penelitian akan diuraikan pada pembahasan di bawah ini:

Tabel 3.1

Rekapitulasi Peningkatan Kemampuan Guru dalam menyajikan pembelajaran Inovatif Melalui Pemanfaatan Lingkungan Sekolah Sebagai sumber Belajar selama Tindakan

\begin{tabular}{|c|c|c|c|c|c|}
\hline No & Uraian & 高 & $\frac{\bar{c}}{\frac{p}{\bar{x}}}$ & 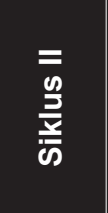 & 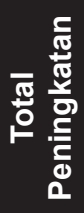 \\
\hline 1 & $\begin{array}{l}\text { Rata-rata Komitmen } \\
\text { Guru }\end{array}$ & 75,9 & 79,2 & 86,4 & 10,5 \\
\hline 2 & $\begin{array}{l}\text { Rata-rata Nilai Skena- } \\
\text { rio Pembelajaran }\end{array}$ & 76,1 & 79,0 & 83,0 & 6,9 \\
\hline 3 & $\begin{array}{l}\text { Rata-rata Kemampuan } \\
\text { Pengajaran Inovatif } \\
\text { Melalui Pemanfatan } \\
\text { Lingkungan Sekolah }\end{array}$ & 70,9 & 79,0 & 83,23 & 12,3 \\
\hline 4 & $\begin{array}{l}\text { Prosentase Kompoten- } \\
\text { si Guruyang mampu } \\
\text { Menyajikan pembelaja- } \\
\text { ran Inovatif }\end{array}$ & $\begin{array}{l}20 \\
\%\end{array}$ & $\begin{array}{l}60 \\
\%\end{array}$ & $90 \%$ & $70 \%$ \\
\hline
\end{tabular}

Grafik I

Histogram Peningkatan Komitmen Guru Dalam Menyajikan Pembelajaran Inovatif melalui Pemanfaatan Lingkungan Sekolah Sebagai Sumber Belajar Pada Guru Agama Hindu Gugus Blahbatuh Th. 2014/2015

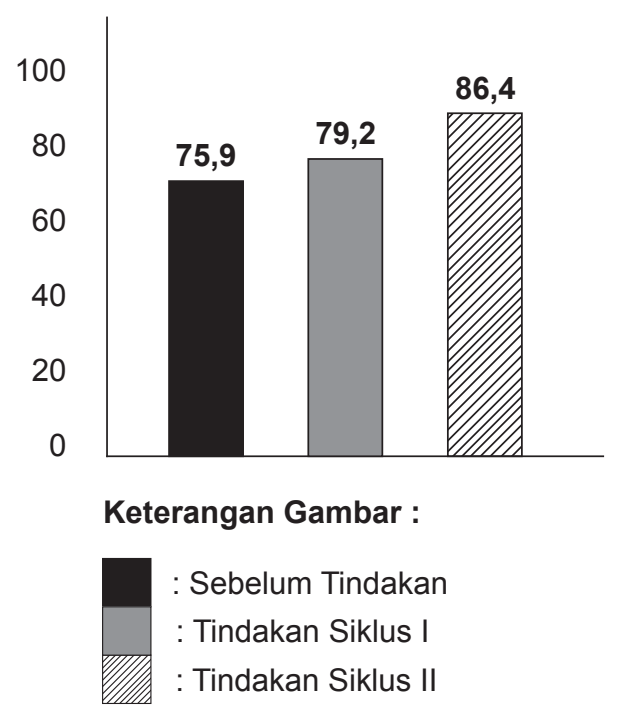

\section{Grafik II}

Histogram Peningkatan Guru Dalam Menyusun Skenario Pembelajaran Inovatif melalui Pemanfaatan Lingkungan Sekolah Sebagai Sumber Belajar Pada Guru Agama Hindu Gugus Blahbatuh Th. 2014/2015

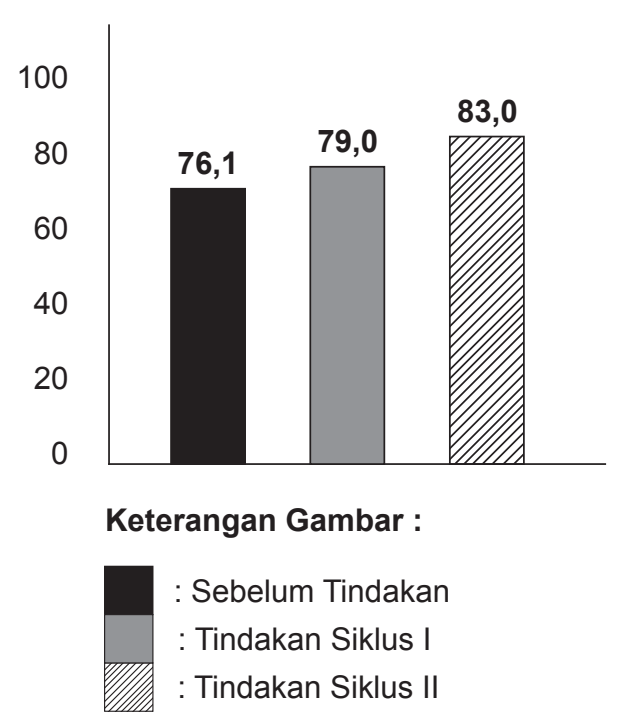


Grafik III

Histogram Peningkatan Kemampuan

Pengajaran Inovatif melalui Pemanfaatan

Lingkungan Sekolah Sebagai Sumber Belajar

Pada Guru Agama Hindu Gugus Blahbatuh Th.

2014/2015

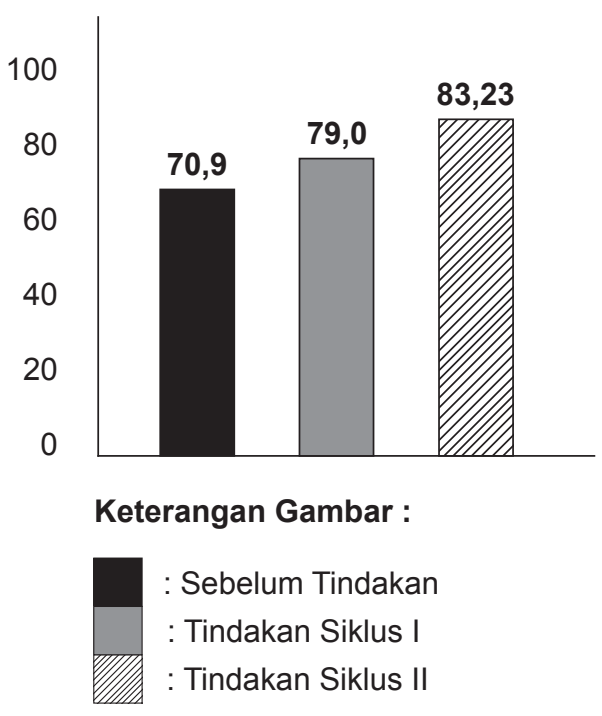

Grafik II

Histogram Persentase Peningkatan

Kemampuan Guru Dalam Menyajikan

Pembelajaran Inovatif melalui Pemanfaatan

Lingkungan Sekolah Sebagai Sumber Belajar

Pada Guru Agama Hindu Gugus Blahbatuh Th. 2014/2015

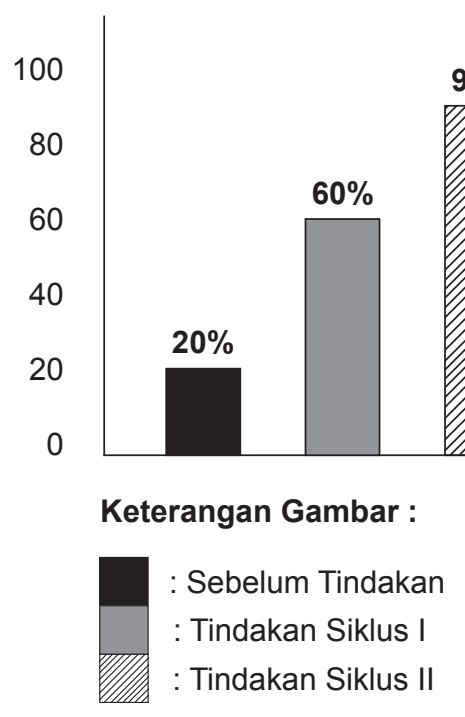

3.3.1 Peningkatan Komitmen Guru dalam dalam menyajikan pembelajaran inovatifmelalui pemanfaatan lingkungan sekolah sebagai sumber belajar

Berdasarkan tabel dan grafik histogram tersebut di atas, Rekapitulasi rata -rata komitmen guru dari pra siklus sampai siklus II Mengalami peningkatan yang signifikan. Peningkatan nilai rata-rata komitmen guru dalam menyajikan pembelajaran inovatif melalui pemanfaatan lingkungan sekolah sebagai sumber belajar mengalami peningkatan yang signifikan yakni sebesar 10,5. Berdasarkan tabel 4.7 nilai komitmen pada pra siklus sebesar 75,9 pada siklus I menjadi 79,2, dan pada siklus II mencapai 86,4 . Pada pra siklus dari 10 orang guru yang terlibat sebagai subjek penelitian 8 orang guru memiliki komitemen dalam kategori cukup, sedangkang hanya 2 orang yang sudah mendapat skor dengan katagori "baik. Melalui kegiatan KKG pemanfaatan lingkungan sekolah sebagai sumber Belajar pada siklus I jumlah guru yang mendapat skor dalam katagori baik mengalami peningkatan sebanyak 3 orang, dan pada siklus II 9 dari sepuluh guru agama Hindu sudah mendapat skor dalam kategori Baik.

\subsubsection{Peningkatan Kemampuan Menyusun Skenario Pembelajaran}

Secara rinci berdasarkan tabel dan grafik histogram peningkatan kemampuan guru dalam menyusun skenario melalui pemanfaatan lingkungan sekolah sebagai sumber Belajar sebesar 6,9 hal ini terlihat dari rata-rata nilai pra siklus sebesar 76.1 pada siklus I meningkat menjadi 79,0 dan pada siklus II menjadi 83,0. Sedangkan jumlah guru yang sudah mampu menyusun sknario pembelajaran sesuai dengan instrument yang telah ditetapkan secara rinci pada pra siklus berjumlah 2 orang, pada siklus I menjadi 6 orang dan pada siklus II menjadi 10 orang. Atau dengan kata lain semua guru yang menjadi subjek penelitian sudah mampu menyusiun skenario pembelajaran.

\subsubsection{Peningkatan kemampuan pengajaran Inovatif melalui pemanfaatan lingkungan sekolah sebagai sumber belajar}

Secara rinci perolehan nilai rataratapeningkatan kemampuan guru memanfaatkan lingkungan sekolah sebagai sumber belajar yaitu nilai rata-rata kegiatan pembelajaran atau dalam proses belajar mengajar dari awal siklus sampai siklus II mengalami peningkatan sebesar 12,3 yakni dengan nilai rata-rata 70,9 pada pra siklus, 79,0 
di sklus I dan menjadi 83, 23 pada siklus II. Jumlah guru yang sudah mampu melaksanakan pengajaran inovatif dengan memanfaatkan lingkungan sekolah sebagai sumber belajar sesuai dengan instrument yang telah ditetapkan secara rinci pada pra siklus berjumlah 2 orang, pada siklus I menjadi 6 orang dan pada siklus II menjadi 9 orang. Sehingga dari hal tersebut diatas, secara keseluruhan persentase peningkatan kemampuan guru dalam menyajikan pembelajaran Inovatif melalui pemanfaatan lingkungan sekolah adalah pada awal siklus mencapai $20 \%$ pada siklus I meningkat menjadi $70 \%$ dan pada siklus II menjadi $90 \%$.

\section{IV.PENUTUP}

Berdasarkan hasil analisis dan pembahasan siklus I dan siklus II tersebut di atas, maka dapat disimpulkan bahwa rekapitulasi rata-rata komitmen guru dari pra siklus sampai siklus II Mengalami peningkatan yang signifikan. Peningkatan nilai rata-rata komitmen guru dalam menyajikan pembelajaran inovatif melalui pemanfaatan lingkungan sekolah sebagai sumber belajar mengalami peningkatan yang signifikan yakni sebesar 10,5. Berdasarkan tabel 4.7 nilai komitmen pada pra siklus sebesar 75,9 pada siklus I menjadi 79,2, dan pada siklus II mencapai 86,4. Pada pra siklus dari 10 orang guru yang terlibat sebagai subjek penelitian 8 orang guru memiliki komitemen dalam kategori cukup, sedangkang hanya 2 orang yang sudah mendapat skor dengan katagori "baik. Melalui kegiatan KKG pemanfaatan lingkungan sekolah sebagai sumber Belajar pada siklus I jumlah guru yang mendapat skor dalam katagori baik mengalami peningkatan sebanyak 3 orang, dan pada siklus II 9 dari sepuluh guru agama Hindu sudah mendapat skor dalam kategori Baik.

Peningkatan kemampuan guru dalam menyusun skenario melalui pemanfaatan lingkungan sekolah sebagai sumber Belajar sebesar 6,9 hal ini terlihat dari rata-rata nilai pra siklus sebesar 76.1 pada siklus I meningkat menjadi 79,0 dan pada siklus II menjadi 83,0. Sedangkan jumlah guru yang sudah mampu menyusun sknario pembelajaran sesuai dengan instrument yang telah ditetapkan secara rinci pada pra siklus berjumlah 2 orang, pada siklus I menjadi 6 orang dan pada siklus II menjadi 10 orang. Atau dengan kata lain semua guru yang menjadi subjek penelitian sudah mampu menyusiun skenario pembelajaran.

Rata-rata peningkatan kemampuan guru memanfaatkan lingkungan sekolah sebagai sumber belajar yaitu nilai rata-rata kegiatan pembelajaran atau dalam proses belajar mengajar dari awal siklus sampai siklus II mengalami peningkatan sebesar 12,3 yakni dengan nilai rata-rata 70,9 pada pra siklus, 79,0 di sklus I dan menjadi 83, 23 pada siklus II. Jumlah guru yang sudah mampu melaksanakan pengajaran inovatif dengan memanfaatkan lingkungan sekolah sebagai sumber belajar sesuai dengan instrument yang telah ditetapkan secara rinci pada pra siklus berjumlah 2 orang, pada siklus I menjadi 6 orang dan pada siklus II menjadi 9 orang. Sehingga dari hal tersebut diatas, secara keseluruhan persentase peningkatan kemampuan guru dalam menyajikan pembelajaran Inovatif melalui pemanfaatan lingkungan sekolah adalah pada awal siklus mencapai $20 \%$ pada siklus I meningkat menjadi $70 \%$ dan pada siklus II menjadi $90 \%$.

Sehinga beranjak dari kondisi tersebut di atas, dapat disimpulkan: Ada Relevansi peningkatan kemampuan guru dalam menyajikan pembelajaran Inovatif dengan pemanfaatan lingkungan sekolah sebagai sumber belajar melalui pendekatan diskusi kelompok kerja guru (KKG) di Sekolah Dasar Gugus Kecamatan Blahbatuh, Kabupaten Gianyar Tahun Pelajaran 2014/2015.

Dari simpulan tersebut di atas, disarankan :Kepada.guru-guru khususnya guru di Sekolah Dasar Gugus Blahbatuh, Kecamatan Blahbatuh , Kabupaten Gianyar,di dalam menyusun skenario pembelajaranagar memanfaatkan semaksimal mungkin lingkungan sekolah dan lingkungan siswa yang sesuai dengan materi pembelajaran sebagai sumber belajar, dan mengintensifkan diskusi KKG dalam memecahkan masalah yang dihadapi 


\section{DAFTAR PUSTAKA}

Badru Zaman, dkk. 2005. Media dan Sumber Belajar TK. Buku Materi Pokok PGTK 2304. Modul 1-9. Jakarta Universiats Terbuka.

Ekowati, Endang. 2001. Stategi Pembelajaran Kooperatif. Modul Pelatihan Guru Terintegrasi Berbasis Kompetensi. Jakarta : Depdiknas.

Kasianto, I Wayan 2004 Meningkatkan Prestasi Belajar Siswa dengan Pendekatan Diskusi Kelompok. Laporan Penelitian Kelas. Tidak dipublikasikan

Rusyan Tabrani. 2001. Pendekatan dalam Proses Belajar Mengajar. Bandung Remaja Rosdakarya.

Sarman, Samsuni S.Pd. 2005. Implementasi Pendekatan Works Based Learning pada Sumber Belajar Masyarakat dalam Pembelajaran PS-Ekonomi. Laporan Penelitian Tindakan Kelas. Banjarmasin. Tidak dipublikasikan.

Sutrisno Hadi, 2000. Metodelogi Penelitian. Yogyakarta : Andi 